\title{
Populists, authoritarians, or securitarians? Policy preferences and threats to democratic governance in the modern age
}

\author{
John R. Hibbing ${ }^{1}$ (1)
}

Received: 30 July 2021 / Accepted: 18 November 2021 / Published online: 10 January 2022

(c) The Author(s), under exclusive licence to Institute for Global Public Policy, Fudan University 2021

\begin{abstract}
What really motivates the hardcore followers of leaders, such as Viktor Orban in Hungary, Jair Bolsonaro in Brazil, Narendra Modi in India, and Rodrigo Duterte in the Philippines? According to standard accounts, it is either a desire for strong authoritative leaders or a desire to empower ordinary people at the expense of elites. Using the ardent supporters of Donald Trump as a case study, I argue that conventional wisdom is unable to explain important recent events such as the documented tendency of Trump supporters to defy COVID-19-inspired authoritative mandates to wear masks and socially distance. On the basis of original survey data, I suggest that the real motivation of Trump supporters and by extension the supporters of similar leaders around the world is an intense desire for policies that protect the insider core of society from the threats posed by human outsiders, such as immigrants, minorities, and norm violators.
\end{abstract}

Keywords Authoritarians · Populists · Trump supporters · Immigration · Democracy

\section{Introduction}

Milos Zeman in the Czech Republic, Narendra Modi in India, Rodrigo Duterte in the Philippines, Jair Bolsonaro in Brazil, Jaroslav Kaczynski in Poland, Donald Trump in the United States, Sebastian Kurz in Austria, Recep Erdogan in Turkey, Benjamin Netanyahu in Israel, Vladimir Putin in Russia, and Viktor Orban in Hungary all have led their respective countries. Marine Le Pen in France, Nigel Farage in the United Kingdom, Geert Wilders in the Netherlands, Doug Ford in Canada, Jimmie Akesson in Sweden, Pauline Hanson in Australia, and Makoto Sakurai in Japan, though not coming to full power, exerted political influence-sometimes

John R. Hibbing

jhibbing@unl.edu

1 Department of Political Science, University of Nebraska-Lincoln, 12th and R Streets, Lincoln, NE 68588, USA 
substantial influence - in their respective countries. These individuals are cut from the same cloth, sharing an approach, an agenda, and a style. They sound the same notes, appeal to the same followers, and advocate the same policies. They are part of a particular political gestalt that, though anything but new, has become remarkably salient in recent decades.

But what exactly is that unifying theme or shared orientation? What is the common denominator and why does it manifest itself in such similar guises in such farflung places? Answering these questions is an important task for analysts of world politics. Given the near universal presence of this orientation; given the intense appeal a sizable subset of citizens feels toward leaders who embody it; given that it has altered the policies of so many countries; and given that it poses a threat to democratic governance, any real understanding of politics must come to terms with whatever it is. To misdiagnose the shared orientation of the leaders listed above is to misdiagnose politics.

The common thread of these puzzlingly powerful, wholly energized political movements is populism (Lind, 2016; Baker, 2017; De la Torre, 2018; Rowland, 2019; Dewan, 2020; Viola-Gaudefroy, 2021). No, it is authoritarianism (Altemeyer, 2016; Applebaum, 2020; Bernstein, 2017; Dean \& Altemeyer, 2020; Gordon, 2016; Gray, 2017; Illing, 2016; Linden, 2017; MacWilliams, 2016, 2020; Ross, 2016; Taub, 2016; Womick et al., 2018). No, it is a mixture of populism and authoritarianism (Kellner, 2018; Norris \& Inglehart, 2019). In combination or alone, it is surely the case that populism and authoritarianism are the most frequently posited labels for the phenomenon of interest. However, despite their popularity, these terms ultimately fail to satisfy and in some instances give the wrong idea about the nature of the orientation and the challenges it poses for policymakers and defenders of democracy.

In this article, I discuss the problems that result from applying terms such as populist and authoritarian to the leaders mentioned and especially to their followers. Then, I suggest an alternative that I believe better captures the essence of these individuals. I support these claims by presenting the results of a select number of original survey items that were administered to representative U.S. samples in 2019 and 2020, during the latter stages of the Presidency of Donald Trump. These survey items clarify the motivations of Trump's base. More importantly, given that Trump is an archetype of the sort of leader we seek to understand, it is likely that the motivations of his followers are quite similar to the motivations of the followers of kindred politicians around the world. A detailed portrait of Trump's fervid supporters allows us to come to grips with the nature of modern politics more generally.

\section{Populists?}

"Populism" is notoriously difficult to define. Michael Kazin writes that "to be populist, all you have to be is popular" (1998: 271). I would amend that to read, "to be populist, all you have to do is think you are popular." John Judis observes that populism is not a coherent policy program or belief system (2016: 14-15) and Benjamin 
Moffitt sees populism as nothing more than "a political style" (2016: 43-45), implying that it is devoid of policy substance.

Certainly, with regard to economic policies, populists are "all over the place" (Freidman 2017). Juan and Eva Peron were authentically eager to improve the lot of working-class Argentinians and, in the 1930s United States, Huey Long put forward a stunningly progressive economic plan, including meaningful inheritance taxes and annual caps on income, all to make possible guaranteed minimum incomes for everyone. In addition, in the modern era, Bernie-Sanders-style progressivism is frequently described as populist. All this is a far cry, however, from the economic agenda of others who have been labeled populists, such as George Wallace, Donald Trump, and Vladimir Putin. To add to the confusion, in Europe, the term populist tends to have a more negative connotation and is not as often attached to economic redistribution. All told, who can argue with Dionne, Ornstein, and Mann's conclusion that "populism is a philosophically slippery concept" (2017: 134)?

A common solution to the term's lack of specificity is to attach a descriptor. In this vein, Cas Mudde describes populism as a "thin ideology" that needs to be paired with a "thick ideology" (2017). For example, Judis suggests the need to distinguish between "right-wing populists" and "left-wing populists" (2016: 14-15) and Pippa Norris and Ronald Inglehart see populism on its own as nothing more than governing on the basis of populist rhetoric, without any indication of "what should be done." As a result, they distinguish between "authoritarian populism" and "libertarian-populism" depending on the proclivities of the movement's leader (2019: 4-11). This approach is reasonable on one level but it would seem that in such a formulation the adjectives are doing most of the work, rendering the noun itself nearly superfluous. In other words, what exactly is the difference between a left-wing politician and a left-wing populist politician? The need to incorporate these adjectives raises questions about what is at the core of populism.

As a further illustration of the term's unruliness, one of the most frequently mentioned features of a populist is deep animus toward elites. Populist leaders typically promise to displace corrupt elite insiders who are supposedly insulated from and indifferent to the "voice of the people. Still, who exactly are the elites? The term has been applied in many different ways.

Is the target economic elites? If so, Donald Trump, whose signature policy accomplishment during his Presidency was a large tax break for corporations as well as for wealthy private citizens, would hardly seem to qualify as a populist. In fact, six of Trump's initial high-level appointees, including Treasury Secretary Steve Mnuchin, had ties to a single Wall Street financial firm: Goldman Sachs (Dionne, Ornstein, and Mann 2017: 128).

Or, rather than financial elites, is the target intellectual, media, and cultural elites bent on an agenda of multiculturalism and globalization. If so, Donald Trump, who routinely railed against the power and influence of entrenched elites of this sort, is very much in the populist mold as are his compatriots around the world. He claimed to be a sworn enemy of the complacent, overeducated governing classes and promised to "drain the [elite] swamp" and to eviscerate the "deep state."

Despite these very different meanings, all can agree that at the root of the term populism is populi or the people. It follows, then, that at the core of populism is a 
leader with intimate attachment to "the people;" a leader whose power springs from the people; a leader who speaks for the people; but beyond all that, a leader who, in a form of secular transubstantiation, becomes the people. Alas, even when stripped to this basic etymological level, the concept of a populist remains indeterminate.

Certainly, leaders such as Orban, Duterte, Modi, Erdogan, Trump, and Bolsonaro hold themselves up as champions of the people. They like to remind listeners how much "the people" love them. The trouble is that leaders of this ilk are not alone in their claims to act for the people and against entrenched, powerful elites. Politicians from across the political spectrum in all countries make such assertions and, indeed, in some respects, politicians in democratic countries cannot succeed without a certain level of support from the people. All politicians claim to have a special understanding of what the people want and to be particularly adept at giving it to them. Given these universal tendencies, the populist label, once again, is not all that helpful in distinguishing the particular class of leaders (and their followers) that is of interest here.

Perhaps the best solution to this dilemma is offered by Muller (2016) who asserts that what distinguishes populists is not merely their claim to represent certain people but rather their strong conviction that anybody who disagrees with them is by definition not a "real person." Nigel Farage, one of the leaders of the Brexit movement, famously described the outcome of the vote as "a victory for real people," thus apparently suggesting that $48 \%$ of the British population (those voting against Brexit) are not real people. A typical populist response to evidence that a large number of people are not with them is merely to posit that the dissenters either are not "real people" or that those individuals must have been duped by nefarious forces, such as the aforementioned elites (Muller, 2016; see also, Muller, 2021). The populist leader typically claims a unique ability to define reality for people by positing an unresponsive, even conspiratorial elite that defies their will and works to counter their interests.

Populist leaders may well be particularly prone to employing arguments such as these but non-populist politicians also view their supporters differently from their critics, imbuing supporters with extra dignity and perceiving them to be more deserving, thus rendering the distinction between populists and others nothing more than a matter of degree. Like populist politicians, non-populist politicians seize any opportunity to lambast elites. There is no surer applause line in a political speech than a disparaging remark about some form of elite, and most politicians-populist or not-succumb to that temptation. Thus, the demarcation between a populist and a non-populist remains less than clear (see also Bartels, 2017; Sides et al., 2018).

Moreover, the implication that "the people" and "the elites" are at opposite ends of a single spectrum is erroneous. Populism requires attitudes that are pro-people and not merely anti-elite. As it happens, many ordinary citizens are suspicious of the power and intentions of elites but at the same time have little respect for vox populi. One recent study in the U.S. found that 73.1 percent of a national sample of American adults reported being alarmed by "the public's lack of common sense" and that only 31.2 percent "trusted ordinary people to make important political decisions" (Hibbing et al., 2018). Yet, many of these same individuals had equally negative views of elites (57.5 percent of the sample agreed-and only 11.5 percent 
disagreed - that politicians are "corrupt and selfish"). Earlier survey results suggest that these sentiments have not changed much in the past couple of decades (Hibbing $\&$ Theiss-Morse, 2002). People are not fond of elites but they are also remarkably circumspect about empowering their fellow citizens. Many anti-elitists are not populists who want to shift political power to ordinary people. On its own, an unfavorable view of elites does not make a populist.

\section{Authoritarians?}

Authoritarian is another label that is frequently but confusingly applied to followers of leaders, such as Donald Trump. As with populist, the root word-in this case, authority-should be telling. Authoritarian leaders long to be in a position to give orders. Authoritarian followers long to be in a position to obey orders coming from authoritative leaders. According to the dictionary, an authoritarian prefers "obedience to authority at the expense of personal freedom." Early scholarship, often using Freudian terminology, surmised that such desires were the result of a need to escape feelings of isolation and anxiety that likely were generated by an overbearing parent (Adorno et al., 1950; Fromm, 1941).

Seen in this literal sense, the followers of Trump and others of his ilk hardly qualify as authoritarians. After all, in Canada (Taylor \& Asmundson, 2021), in Denmark (Kornfield, 2020), in the United States (Sami, 2020), and around the world, the followers of that type of politician are the very individuals who were the least likely to obey the COVID-19-inspired urgings of scientists and elected officials to wear masks, to socially distance, and to get vaccinated, claiming such mandates violated their personal freedom. As such, rather than preferring obedience to authority at the expense of personal freedom, it seems the reverse is true: to wit, these individuals value personal freedom at the expense of obedience to authority. In fact, if they value authority at all, it seems to be authority mixed with anarchy.

Such inclinations were even more obviously on display in Washington, DC on January 6, 2021 when thousands of Trump supporters staged an insurrection, engaging in acts that hardly reflected a desire to obey authority. People who smash the doors and windows of an iconic national institution are not authoritarians; people who chant "it's us versus the cops," are not authoritarians; people who use flagpoles as weapons to attack security personnel are not authoritarians; people who steal and destroy government property are not authoritarians; people who threaten to hang the Vice-President of the United States are not authoritarians. Similar, if less overt and violent, demonstrations against authority have taken place around the world.

Given this apparent aversion to authority, the label "authoritarian is obviously a poor description of those who fervently support leaders such as Trump, Erdogan, and Bolsonaro so why has that label been so persistently popular? Terms morph to the point of sometimes taking on a life of their own and such an evolution certainly has occurred with the term "authoritarian."

Thanks to the work of scholars such as Adorno et al. (1950), Altemeyer (1981, 1988, 1996), Feldman (2003), Stenner (2005), Duckitt and Sibley (2009), Duckitt et al., (2010), Sibley and Duckitt (2013), Hetherington and Weiler (2009, 2018), 
Norris and Inglehart (2019), and many others, authoritarians are now thought to possess three traits: a desire to submit to authority figures; a preference for aggressive action; and a proclivity to follow societal norms. Even after this broadening from the original meaning that focused exclusively on submitting to authority, the new meaning still does not seem to match the traits typically observed among avid supporters of Donald Trump and in all likelihood the supporters of similar leaders around the world.

As already pointed out, casual observation indicates Trump supporters are not submissive; but are they conformists who delight in obeying societal norms and are they aggressive in the way they pursue their political goals? Regarding conventionalism, it turns out that Trump supporters only conform to particular conventions and are more than willing to ignore or even directly contradict others. To illustrate, consider two widely known Biblical injunctions. The first, found in the Old Testament, is "an eye for an eye," suggesting that punishment for norm violations should be firm and severe. The second, found in the New Testament, is "turn the other cheek," suggesting that the proper response to mistreatment at the hands of others is meekness, understanding, and perhaps forgiveness. Trump supporters appear to be fully on board with firm punishment but not with meekly enduring harm inflicted by others. Separation of church and state and admitting the world's "poor and huddled masses" into the country are other legitimate norms that Trump supporters denigrate. Rather than being blindly conformist, Trump supporters are highly selective in the edicts toward which they bend. Many Trump supporters delight in disobeying the strictures of polite society and often see themselves not as compliers but as disruptors (Malkin, 2019). It seems, then, that followers of leaders, such as Donald Trump, just as they do not submit to any powerful leader, also are not prone to indiscriminately obey all societal norms. Instead, they only follow those authorities and those societal norms and conventions that champion a specific set of policy positions.

Two previous studies provide systematic support for this conclusion. Using an original, U.S. national survey of over 1400 individuals, Steven Ludeke et al. found no evidence that, compared to those with other political orientations, Trump supporters are more likely to be either submissive or conventional. In fact, the signs for the relationships were in the opposite direction from that expected by popular wisdom, meaning that, if anything, Trump supporters are less, not more, submissive and conventional. In several formulations, the unexpected relationships were not statistically significant though in some they were (Ludeke et al., 2018). Separate studies by Jake Womick and colleagues, using three large convenience samples, similarly find no evidence of the expected significant, positive relationship between Trump support and heightened submissiveness and conventionalism (Womick et al., 2018).

What about the third trait associated with authoritarianism as the term has come to be used in the modern vernacular: aggression? Unfortunately, aggression is a difficult trait to measure in surveys. Events in Charlottesville, Virginia, and Washington, DC certainly suggest there is an aggressive, even violent, element to some of the support for Donald Trump, but are the actions associated with these salient but small incidents indicative of broader tendencies among all supporters? With regard to aggressiveness, the two previously mentioned studies did find Trump devotees to be more likely than those with other political orientations to support aggressive 
responses though even here the conclusion seemed contingent upon the target of the aggression. As Ludeke et al. put it, Trump supporters have "relatively positive attitudes about the use of aggression in the service of in-group goals" (Ludeke et al., 2018: 8; for a similar point, see Feldman, 2003: 67). The obvious implication is that when aggression is not in the service of in-group goals, those supporters may well not be particularly aggressive.

Data collected for me are consistent with these conclusions. In mid-2019, I commissioned the international polling firm YouGov to administer a lengthy set of survey items to a demographically representative sample of American adults $(N=1000)$. I then divided respondents into groups on the basis of their response to a standard ideological, self-placement item: "Generally speaking, do you consider yourself a liberal [in the American sense of the word], moderate, or conservative?" In addition, I distinguished fervent Trump supporters from others by taking note of those individuals who strongly agreed with the following statement: "Donald Trump is one of the very best presidents in the entire history of our country." Even many conservatives, though likely somewhat supportive of Trump, would be unwilling to go this far...but his strongest supporters (17\% of the adult U.S. population) do.

Two of the survey items addressed the concept of submissiveness by ascertaining respondents' desires for a "forceful, mighty leader." However, these two items differed with respect to why the "forceful, mighty leader" was necessary. In one, respondents were asked to indicate whether they strongly agreed, agreed, neither agreed nor disagree, disagreed, or strongly disagreed that "Our country desperately needs a forceful, might leader who will keep us safe from criminal elements and from foreign powers." The other item adopted the same format and stem but specified a very different set of policy objectives. It read: "Our country desperately needs a forceful, might leader who will help and poor and save the Earth's environment." The results are presented in the top half of Table 1 and show that the particular issue objectives pursued by the "forceful" leader made a great difference in people's desires for strong authority.

At one level, the results are not surprising. Trump's base of supporters is quite eager for a "forceful, mighty leader" when that leader is tough on criminals and on foreign powers ( $84 \%$ support) but not all that eager for a "forceful, mighty leader" when that leader is working to redistribute wealth and save the environment (only $35 \%$ ). This result squares with a widely acknowledged sense of the policy priorities of Trump's fervid followers (as well as the followers of similar leaders around the world). However, at another level, these results serve as a clear indication that Trump enthusiasts do not, as the characteristics of an authoritarian imply, merely want "forceful, mighty leaders" regardless of what policy objectives those leaders might seek to accomplish. The core motivation, therefore, is not so much a desire for strong authority in the abstract but rather a desire only for strong authority that prioritizes and works stridently to enact policies that protect in-groups from threats such as those posed by foreign powers and criminal elements.

Recall that another of the three core elements of the modern understanding of authoritarianism is a desire for aggressive action. Is there evidence that Trump's avid followers are particularly eager for aggressive action? As is apparent from the lower panel of Table 1, similar to the situation with regard to powerful leaders, the 


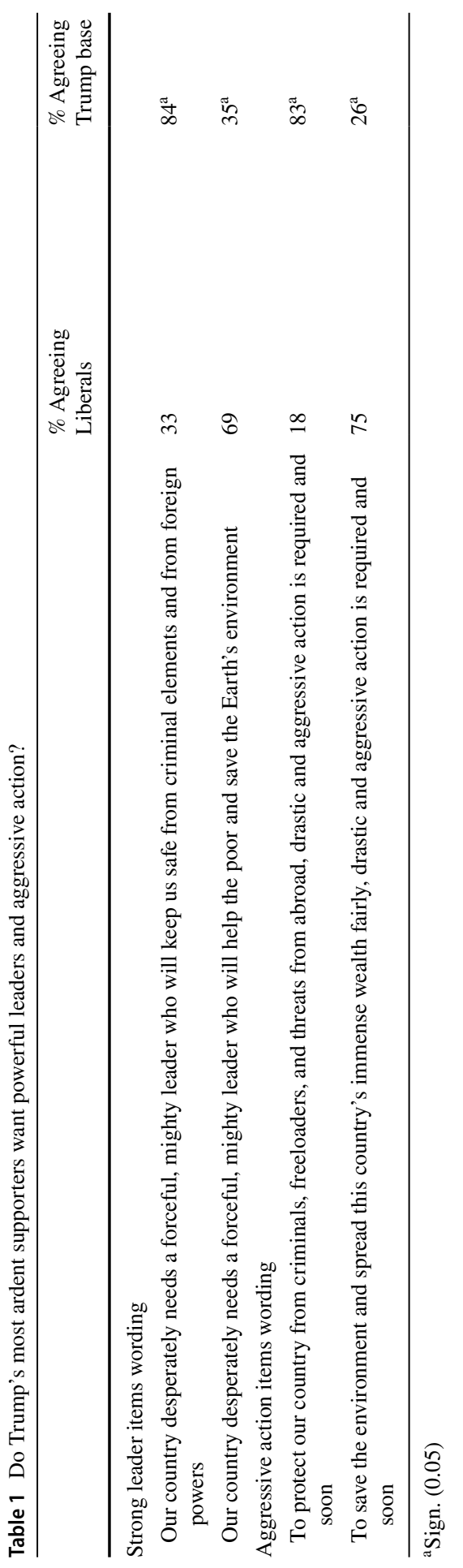


desire for aggressive action depends heavily on what the action is. When the aggressive action promises to protect their country from criminal and external threats, Trump venerators are definitely supportive (83\% agree compared to only $18 \%$ of self-identified liberals). However, when the aggressive action is directed toward saving the environment and spreading the wealth, Trump supporters' view of the merits of aggressive action dips dramatically, garnering only $26 \%$ support (the statement gets $75 \%$ support from self-identified liberals). Rather than asserting that Trump's base is generically desirous of strong leaders engaging in aggressive action, a more accurate conclusion is that they only want such leadership and action in pursuit of a narrow set of policy objectives. In this, they may not be all that different from those at the opposite end of the political spectrum (that is, those locating themselves on the left).

These findings on the highly selective nature of Trump supporters' desire to be led by strong and aggressive leaders are at odds with numerous popular assertions. For example, former U.S. representative and now social media impresario Joe Walsh, on the basis of what he claims are his interactions with "thousands of Trump supporters every day," reports the following: "all they [Trump supporters] want is leaders who will fight. They do not care what they are fighting for...They just want them to fight" (Walsh, 2019). If this claim was true, the data in Table 1 would not have indicated such large shifts in response patterns depending on the specifics of the policies being pursued. Contrary to Walsh's sentiments, Trump supporters' attitude toward mighty and aggressive leaders is heavily influenced by the policies being pursued by those leaders. In other words, the evidence demonstrates that Trump supporters care a good deal about "what the leaders are fighting for."

Unfortunately, the survey did not include a parallel pair of items for devotion to specific norms but if it had, the chances are good that the results would have indicated a similar "conditional" attachment to long-established societal norms. Here, too, the key seems to be the substance and not just a universal proclivity to conform to societal edicts in general. Instead of seeing Trump supporters as being universally submissive, aggressive, and conformist, we need to delineate the particular situations in which they do and do not submit, aggress, and conform. This general message parallels what we found with regard to populism where Trump's fervent followers only invoke "the people" when it suits their purposes.

\section{Authoritarian populists?}

Previous treatments that rely on terms such as populist and authoritarian are commendably cognizant of the terms' problematic features. For example, Norris and Inglehart (2019), who prefer to call supporters of leaders, such as Trump "authoritarian populists," recognize the tension that results from this juxtaposition. Those supporting loyalty and submission (that is authoritarians) generally support institutions designed to preserve social stability and enforce law and order but the preservation of the institutions charged with maintaining stability and order can be directly at odds with the populist impulse to challenge the established, elite-dominated structures of power. How can individuals simultaneously want to submit to and challenge 
elites? The authoritarian deference to authority contradicts the populist resistance to established authority. Besides, the leader of a large group of people typically qualifies as an elite (Norris \& Inglehart, 2019: 74-76), a situation that may force followers to engage in mental gymnastics to justify their support.

John Dean and Bob Altemeyer wrestle with a similar contradiction. They believe that for Trump supporters, submission "is a prerequisite to everything" (2020: 130) and that this desire for submission arises because of deep-seated fear over "what will happen if they stop believing what their authorities say is true" (2020: 149). As such, this concept relates to John Jost's description of system justification (Jost, 2020) in which even those individuals who are not benefiting from the system have the instinct to defend and justify it.

A problem arises, however, in that many of these submissive individuals also score high on desires to dominate as measured by a survey battery referred to as Social Dominance Orientation (Sidanius \& Pratto, 1999). As Dean and Altemeyer admit, many Trump supporters "have impulses to both dominate and submit" (2020: 195), and they readily concede that the desire to submit and the desire to dominate are inconsistent with each other.

The reason terms such as populist and authoritarian run into problems is that they place the emphasis on who will make decisions - either the people (populists) or the authorities (authoritarians) — even though the real distinguishing motivation of people in thrall to leaders such as Trump is substantive and not procedural. If the followers of Donald Trump are any indication — and I believe they are - those devoted to such individuals want particular outcomes, not processes. Thus, the crucial issue becomes specifying the outcomes they desire.

\section{Securitarians}

Given the lack of fit of terms, such as populist and authoritarian, a new label is warranted and I suggest it should be securitarian. What the followers of Trump and others really want is not for the teeming masses to be given more power (populism) or for a domineering leader to tell everyone else what to do (authoritarianism); rather, it is a society in which traditional insiders are protected from the threats they believe are posed by human outsiders. Embracing a form of identity politics, they see insiders as the historical core of their country-those identifying with the dominant race, practicing the dominant religion, speaking the dominant language, and caring about the strength and unity of the country's core. They see outsiders as those not belonging to the aforementioned core. Those who live outside the country are automatically outsiders but so are those on the inside who weaken the core, perhaps because of their appearance, perhaps because of their political beliefs, or perhaps because they are prone to violating norms that protect insiders (Hibbing, 2020).

These political movements, then, are more about policies than is usually implied. The real motivation is not who governs (the masses or a forceful leader) but achieving a particular set of insider-friendly policies: restricting immigration, strengthening national defenses, minimizing the influence of external actors, promoting 
patriotic displays, and protecting the culture from criminals, norm violators, and the moral decay believed to be brought on by diversity.

Previous commentators recognize the nativist, nationalist, ethnocentric, concernwith-outsider-threats aspects of the modern mood (see Dionne et al., 2017; Dean \& Altemeyer, 2020; Norris \& Inglehart, 2019); I am suggesting that they take the next step and use a more accurate label for that mood. Rather than re-defining terms that were clearly coined to describe something else, we should start from scratch with a term that is apt. Since the ultimate goal is security for insiders-security in the face of threats posed by outsider human beings (non-human threats such as environmental collapse and COVID-19 are not nearly as worrisome to them)—securitarian is a term that is more reflective of that central motivation.

The survey mentioned earlier provides evidence that, compared to people with other political orientations, ardent Trump supporters are NOT more likely to crave authority in their lives. Unlike authoritarians, Trump's base actually reacts quite negatively to being told what to do, as was apparent in their responses to COVIDmotivated mask mandates and enforced shutdowns. What they do crave is protection from the threats they see being posed by outsiders.

Comparing the ability of authoritarian items (i.e., those dealing with submission, aggression, and conventionalism) with the ability of securitarian items (i.e., those dealing with strength, security, and preparedness) to differentiate across political groups is instructive. My hypothesis is that, compared to the authoritarian items, the securitarian items will produce greater differences between Trump venerators and self-identified liberals and even between Trump venerators and conservatives who do not venerate Trump (remember venerators are defined here as those who strongly agree that Donald Trump was one of the very best presidents in the entire history of the country).

The data in Table 2 come from the same survey as the data in Table 1 and are clearly supportive of this hypothesis. The differences between self-identified liberals and Trump venerators on the three authoritarian personality items tapping submission, aggression, and conventionalism are relatively small (12, 20 and 7 points, respectively) and the differences do not always reach statistical significance, even at the 0.1 level. The strongest support for conventional wisdom is for the item on aggression (Trump venerators are significantly more likely than liberals to have been in a physical fight). In one of the cases in which the difference is statistically significant, the direction of the relationship actually is opposite to that expected by conventional wisdom. Ardent Trump supporters are significantly LESS submissive than liberals in that they express a greater desire to be "independent of others." Though contrary to conventional wisdom, this relationship is perfectly consistent with the reluctance of many Trump venerators to obey the edicts of authority figures on COVID-19 related matters.

Table 2 also contains results for those individuals who identify as conservative but who do not venerate Donald Trump (non-Trump-venerating-conservatives or “NTVCs). Differences between Trump's base and conservatives who are not part of that base are modest, just 4 points, 6 points, and 4 points. In sum these "authoritarian" items clearly are not tapping the core of what distinguishes avid Trump supporters from others. 
Table 2 Authoritarian personality items and securitarian personality items

\begin{tabular}{|c|c|c|c|}
\hline & $\begin{array}{l}\% \text { Agreeing } \\
\text { Liberals }\end{array}$ & $\begin{array}{l}\% \text { Agreeing } \\
\text { NTVCs }^{\mathrm{a}}\end{array}$ & $\begin{array}{l}\% \text { Agreeing } \\
\text { Trump base }\end{array}$ \\
\hline \multicolumn{4}{|l|}{ Authoritarian personality items } \\
\hline $\begin{array}{l}\text { I prefer to be independent of others and largely self-suffi- } \\
\text { cient }\end{array}$ & 70 & 78 & $82^{\mathrm{b}}$ \\
\hline $\begin{array}{l}\text { During my time as an adult, I have been in at least one } \\
\text { physical fight }\end{array}$ & 18 & 32 & $38^{\mathrm{b}}$ \\
\hline Sometimes I enjoy ruffling the feathers of "proper" society & 46 & 35 & 39 \\
\hline \multicolumn{4}{|l|}{ Securitarian personality items } \\
\hline $\begin{array}{l}\text { Projecting weakness is just about the worst thing a person } \\
\text { could do }\end{array}$ & 27 & 42 & $60^{\mathrm{b}}$ \\
\hline $\begin{array}{l}\text { I think a good deal about the security of my family and my } \\
\text { country }\end{array}$ & 45 & 78 & $86^{\mathrm{b}}$ \\
\hline $\begin{array}{l}\text { "Being prepared" to face threats is the best motto for living } \\
\text { one's life }\end{array}$ & 41 & 71 & $80^{\mathrm{b}}$ \\
\hline \multicolumn{4}{|l|}{ Securitarian worldview items } \\
\hline $\begin{array}{l}\text { A central goal for our country should be to become so } \\
\text { strong that outsiders will realize it does not make sense to } \\
\text { attack us }\end{array}$ & 29 & 73 & $88^{\mathrm{b}}$ \\
\hline $\begin{array}{l}\text { If we are not vigilant, we will quickly be victimized by } \\
\text { criminals, immigrants, and by the power of foreign } \\
\text { countries }\end{array}$ & 18 & 72 & $88^{\mathrm{b}}$ \\
\hline $\begin{array}{l}\text { Just about the worst thing for a country is to be perceived } \\
\text { as weak }\end{array}$ & 32 & 76 & $88^{\mathrm{b}}$ \\
\hline
\end{tabular}

${ }^{\mathrm{a}}$ Non-Trump-venerating conservatives

${ }^{\mathrm{b}}$ Sign. (0.05) [between Liberals and Trump's Base]

Do the "securitarian personality" items do better? Substantially. When the focus of the items shifts to strength, security, and preparedness, differences in responses across the various political orientations jump. Compared to self-identified liberals, those who can be considered a part of Trump's base are 33 points more likely to worry about projecting weakness, 41 points more likely to worry about family security, and 39 points more likely to believe that "being prepared" is the best motto for living one's life. In addition to being many times the size of the differences observed for authoritarian items, all of the differences in the securitarian personality items are in the expected direction and statistically significant.

Sizable differences persist even when confining the focus to the right side of the political spectrum. Between individuals who venerate Donald Trump and those conservatives who do not strongly agree that Trump is "one of the best presidents ever," the differences are 18 points on the "projecting weakness" item, 8 points on the "family security" item, and 9 points on the "being prepared" item. Unlike the authoritarian personality items, all three of the differences between Trump venerators and non-Trump-venerating conservatives are in the expected direction and statistically significant (0.05 level; not shown). The securitarian 
personality items differentiate Trump's strongest supporters in a way that authoritarian items simply do not.

One of the confusing features of research in this area is that, in trying to understand the substructure of political differences, survey items sometimes tap personality traits but other times tap what might be called worldview. In other words, some items solicit information on the personal-for example, "I like it when others make decisions for me"-and some on broader questions pertaining to country and society-for example, "it is possible for a country to be great without being militarily strong."

As can be seen in the bottom panel of Table 2, when the focus is on securitarian worldview the differences across the political spectrum are substantial. Most liberals do not agree that national vigilance and strength are essential but nearly 9 out of 10 Trump venerators (in other words, those constituting Trump's base), agree that a central goal for the country should be strength, that vigilance is essential, and that it is terrible for a country to be perceived as weak. The differences between liberals and Trump venerators are remarkable (59 point, 70 points, and 56 points, respectively) and even the differences between Trump venerators and conservatives who are not Trump venerators are notable (15 points, 16 points, and 12 points). What really sets Trump's base apart from other conservatives is securitarianism.

\section{Why it matters: policy consequences}

This more accurate delineation of the motivations of ardent Trump supporters helps to explain puzzles such as why people described as populist could support drastic restrictions on voting rights; why people described as authoritarian could rebel against authorities in state capitals and ultimately, on January 6, 2021, in Washington, DC itself; and why individuals who belong to these movements so often advocate policies at odds with their own economic interests. Protective trade policies such as tariffs on Chinese goods hurt soybean farmers in the Midwest just as Brexit hurt many working-class merchants in the U.K. yet these individuals often continued to support those policies, because they believed standing up to foreign entities such as China or Brussels to be more important than personal economic gain (Long \& Clement, 2018).

To some extent, the policy desires of those who follow leaders such as Bolsonaro, Modi, Orban, Le Pen, and Trump are predictable. They value the core of their country and want to do everything possible to keep that core pure, unified and impenetrable. This translates into support for defense spending (Trump), opposition to outside influences (Farage), stiff sentences for criminals (Duterte), support for historically dominant customs, language, and religion (Modi), and immigration restrictions (all of them). These policies constitute the standard playbook for leaders of this stripe, because these are the policies their followers want. Those followers would not revere an authority figure who failed to champion securitarian policies. Contrary to many previous claims, the ultimate goal of these followers is policy and not leadership style. 
It is often said that Donald Trump's supporters would stick with him no matter what he did. This is not true. If he advocated cutting defense spending, decommissioning police forces, enacting new gun control legislation, and pursuing open borders, they would turn on him with alacrity. His followers want insider-promoting policies; not a government dominated by ordinary people or authoritarian leaders.

These policy desires set up an inevitable clash with individuals who want to embrace people who are different. In fact, the central political division now and always, dating from evolutionary times is how a society should treat outsiders: welcome them with open arms or keep them at arm's length? Matters of identity, acceptance, belongingness, immigration, culture, in-groups, and out-groups create a volatility in politics that does not exist when debates revolve around taxation, center-periphery relationships, and even social policy, though it should be noted that matters of identify, insiders, and outsiders often bleed into debates on economic and social policies. For example, even where an expansive welfare state is accepted by all political parties (e.g., Denmark), intense disputes erupt over whether recent immigrants should be eligible to receive benefits. Policy makers would do well to recognize the centrality, intractability, and explosiveness of securitarian issues.

\section{Why it matters: threats to democracy}

In the wake of these movements, modern defenders of democracy are primarily concerned about possible authoritarian takeovers. The worry is that authoritarian leaders will silence critics, coopt the military, disband the judiciary, ban independent media, and eliminate dissent. This threat should never be taken lightly as is illustrated by recent events in countries, such as Hungary. However, in other countries authoritarian encroachment has been held at bay. In some of these countries, such as the United States, the evidence presented here suggests that a polar opposite threat also needs to be taken seriously: a securitarian-inspired fracturing in which a significant minority of the population withdraws into isolated sectors of the web as well as physical society, displaying abject hostility toward any attempt at national and especially supra-national governance. In other words, in addition to worrying about too much effective authority, we also need to worry about too little. Threats to democracy are posed not only by overly centralized authority and obsequious followers but also by survivalists, militia members, noncompliers, polarization, splintering, and the enervated, hamstrung leaders that result. At root, those most loyal to Donald Trump are disruptors, not conformists (Malkin, 2019). Their instinct is to resist authority rather than submit to it and this characteristic poses a quite different threat to democracy. Anarchy becomes as much a concern as too much authority.

The commitment of securitarians to democracy is half-hearted. If evidence for this statement is needed, it can be found in the first row of Table 3. Here we see that to achieve their desired goal of establishing a country that is secure, 59\% Trump's base would sacrifice democracy. For them, security for the country's core trumps democracy. Self-identified liberals, not surprisingly, feel quite differently and only $13 \%$ of them would make that tradeoff. 
Table 3 Commitment to democracy items

\begin{tabular}{|c|c|c|c|}
\hline & $\begin{array}{l}\% \text { Agreeing } \\
\text { Liberals }\end{array}$ & $\begin{array}{l}\% \text { Agreeing } \\
\text { NTVCs }\end{array}$ & $\begin{array}{l}\text { \% Agreeing } \\
\text { Trump base }\end{array}$ \\
\hline \multicolumn{4}{|l|}{ Commitment to democracy items } \\
\hline $\begin{array}{l}\text { If a country had to choose between being } \\
\text { secure and being democratic, being } \\
\text { secure would be the way to } \text { go }^{\mathrm{a}}\end{array}$ & 13 & 46 & $59^{\mathrm{b}}$ \\
\hline $\begin{array}{l}\text { If a country had to choose between sig- } \\
\text { nificantly improving the environmental } \\
\text { health of the planet or having a demo- } \\
\text { cratic form of government, improving } \\
\text { the environment would probably be the } \\
\text { way to go }{ }^{c}\end{array}$ & 41 & 25 & $20^{\mathrm{b}}$ \\
\hline
\end{tabular}

${ }^{\mathrm{a}}$ Results from a 2019 survey

bSign. (0.05) [between Liberals and Trump's Base]

${ }^{\mathrm{c}}$ Results from a 2020 survey

Are liberals that much different, however, in their willingness to sacrifice democracy to enact their favored policies, such as saving the environment and redistributing wealth? The second row in Table 3, presenting data from a 2020 survey (but parallel to the 2019 survey in that it was done for me by YouGov on a demographically representative sample of American adults of over 1000 respondents) suggests the difference is only marginal. Here the policy alternative to democracy was changed from being secure to "significantly improving the environmental health of the planet." Of course, those on the political left see this as a trick question. What good is democracy if the planet has been ruined? Fair point, but the left needs to realize that, as crazy as it seems to them, securitarians feel much the same way. For securitarians, a weakening of the core culture is on direct par with total planetary collapse.

Precise comparisons of the two items should be undertaken cautiously, particularly since the results are derived from surveys that were conducted more than a year apart, but the relevant point here is that the pattern flips when the policy objective flips. For too many people ( $41 \%$ on the left and a sizable $59 \%$ on the right), commitment to democracy is something they would sacrifice to achieve the policy outcome they want (also see Graham and Svolik 2019).

\section{Conclusion}

The ascendance of a particular class of politicians and their fiercely loyal followers, has greatly affected the policies and democratic stability of numerous countries. In this essay, I suggested it is preferable to view these movements and leaders as securitarian rather than populist or authoritarian. The latter two phrases place the emphasis on how decisions are made - either by the people or by a strong authority figure-when in fact the key objective of these leaders and their rabid followers is to accomplish certain policy objectives-specifically the protection of insiders in their 
respective countries from the threats that they perceive to be presented by outsider human beings. These outsider threats to insiders are believed to be existential so they are matters of deep concern perhaps in no small part, because worries about human outsider threats were central to our hunter-gatherer ancestors and thus are primordial and deeply embedded.

Such powerfully felt policy objectives (end immigration; deter threats, enforce codes of conduct, and promote core religion, language, and customs) mean many securitarians are willing to sacrifice democracy to get the identity politics they crave. Trump's followers were fine with democracy when it produced the electoral outcome they wanted in 2016 (Trump's victory) but they turned on democracy with a vengeance when the outcome in 2020 was not to their liking. In a variety of ways, this "democracy-only-when-it-suits-our-purposes" mindset threatens democracies which by their nature are fragile (Levitsky \& Ziblatt, 2018; Somit \& Peterson, 1997).

One threat to democracy has not garnered as much attention as it should, no doubt in part because of all the focus on authoritarianism. The characteristics of the fervid followers of Donald Trump make democracy susceptible not just to too much authority but also to too little. If one-fifth to one-fourth of the population (this seems to be the approximate range of support for securitarian leaders in a surprising number of countries including the U.S.) views their own government as essentially an illegitimate foreign entity, polities may become ungovernable. This particular challenge to democracy may be especially visible if securitarians believe insider influence in society is diminishing and their policy desires are being ignored, as will almost certainly be the case in light of demographic trends and the defeat of securitarian leaders, such as Trump. His followers may well direct their energies to renegade militias, conspiracy theories, vigilante justice, survivalist (prepper) communities, and efforts to challenge and weaken government. The January 6, 2021 events in Washington DC demonstrate that this threat is not merely hypothetical.

In the wake of the Trump Presidency, the imminent danger posed by his most loyal followers is not authoritarianism but anarchy; it is not omnipotent leaders but anemic ones. A belief that Trump supporters are authoritarians is not just a semantic error; it may lead those who are worried about the health and stability of democracy to look over just one shoulder when they need to be looking over both. In the United States and around the world, the danger posed by the followers of leaders similar to Donald Trump is not only that they will enable an all-powerful, homogenizing government but also that, due to their aversion to many sources of legitimate authority, they will actively work to emasculate any government that they believe is too interested in globalization and interdependence. Those who value democracy should be on guard for a situation in which citizens are forced to be unified but they also should not forget about the dangers posed by citizens who opt to be insular, exclusionary, and divisive.

\section{Declarations}

Conflict of interest Author declare that they have no conflict of interest. 


\section{References}

Adorno, T. W., Frenkel-Brunswik, E., Levinson, D. J., \& Sanford, N. R. (1950). The authoritarian personality. Harper \& Brothers.

Altemeyer, B. (2016). Donald trump and authoritarian followers. In: The authoritarians. https://www. theauthoritarians.org/donald-trump-and-authoritarian-followers/.

Altemeyer, B. (1981). Right-wing authoritarianism. University of Manitoba Press.

Altemeyer, B. (1988). Enemies of freedom: understanding right-wing authoritarianism. Jossey Bass.

Altemeyer, B. (1996). The authoritarian specter. Harvard University Press.

Applebaum, A. (2020). Twilight of democracy: The seductive lure of authoritarianism. Doubleday.

Baker, P. (2017). Jackson and trump: How the two populist presidents compare. New York Times. https://www.nytimes.com/2017/03015/us/politics/Donald-trump-andrew-jackson.html.

Bartels, L.M. (2017). The wave of right wing populist sentiment is a myth. The Washington Post. https://www.washingtonpost.com/news/monkey-cage/wp/2017/06/21/the-wave-of-right-wingpopulist-sentiment-is-a-myth/.

Bernstein, J.M. (2017). Adorno's uncanny analysis of trump's authoritarian personality. Public Seminar. http://www.publicseminar.org/2017/10/adornos-uncanny-analysis-of-trumps-authoritarianpersonality/.

De la Torre, C. (2018). Populism revived: donald trump and the latin american leftist populists. The Americas, 75(4), 733-753.

Dean, J. W., \& Altemeyer, B. (2020). Authoritarian nightmare. Melville House.

Dewan, A. (2020). Trump's loss dealt a blow to global populism but the movement is still alive and kicking. CNN. November 27, 2020. https://www.cnn.com/2020/11/27/world/trump-electiondefeat-populism-global-intl/index.html.

Dionne, E. J., Ornstein, N. J., \& Mann, T. E. (2017). One nation after trump: A guide for the perplexed, the disillusioned, the desperate, and the not-yet deported. St. Martin's Press.

Duckitt, J., Bizumic, B., Krauss, S. W., \& Heled, E. (2010). A tripartite approach to right-wing authoritarianism. Political Psychology, 31(5), 685-715. https://doi.org/10.1111/j.1467-9221. 2010.00781.x

Duckitt, J., \& Sibley, C. G. (2009). A dual-process motivational model of ideology, politics, and prejudice. Psychological Inquiry, 20(2-3), 98-109. https://doi.org/10.1080/10478400903028540

Feldman, S. (2003). Values, ideology, and the structure of political attitudes. In D. O. Sears, L. Huddy, \& R. Jervis (Eds.), Oxford handbook of political psychology (pp. 477-508). Oxford University Press.

Friedman, U. (2017). What is a populist and is Donald trump one?. Atlantic. https://www.theatlantic. com/international/archive/2017/04/what-is-nativist-trump/521355/.

Fromm, E. (1941). Escape from freedom. Holt, Rinehart, and Winston.

Gordon, P.E. (2016). The authoritarian personality revisited: Reading Adorno in the age of trump. b2o. https://www.boundary2.org/2016/06/peter-gordon-the-authoritarian-personality-revisitedreading-adorno-in-the-age-of-trump/.

Graham, M., and Svolik, M.W. (2019). Democracy in America: Partisanship, polarization, and the robustness of support for democracy in the U.S. Yale University Working Paper. https://www.bu. edu/polisci/files/2019/09/Graham-and-Svolik-Democracy-in-America-web-1ngqg71.pdf.

Gray, P. (2017). Childrearing beliefs were best predictor of trump support. Psychology Today. https:// www.psychologytoday.com/us/blog/freedom-learn/201702/childrearing-beliefs-were-best-predi ctor-trump-support.

Hetherington, M. J., \& Weiler, J. D. (2009). Authoritarianism and polarization in American politics. Cambridge University Press.

Hetherington, M. J., \& Weiler, J. D. (2018). Prius or pickup? How the answers to four simple questions explain Americans great divide. Houghton Mifflin Harcourt.

Hibbing, J.R., Theiss-Morse, E., Hibbing, M.V. and Fortunato, D. (2018). Who do people want to govern and how? The style of democracy preferred by Americans. In: Paper presented at the American Political Science Associate Meetings, Boston, MA, August-September, 2018.

Hibbing, J. R. (2020). The securitarian personality: what really motivates trump's base and why it matters in the post-trump era. Oxford University Press.

Hibbing, J. R., \& Theiss-Morse, E. (2002). Stealth democracy: Americans' beliefs about how government should work. Cambridge University Press. 
Illing, S. (2016). If you want to understand the age of trump, read the frankfurt school. Vox. https:// www.vox.com/conversations/2016/12/27/14038406/donald-trump-frankfurt-school-brexit-criti cal-theory.

Jost, J. T. (2020). A theory of system justification. Harvard University Press.

Judis, J. (2016). The populist explosion. Columbia Global Reports.

Kazin, M. (1998). The populist persuasion. Cornell University Press.

Kellner, D. (2018). Donald trump as authoritarian populist. In J. Morelock (Ed.), Critical theory and authoritarian populism (pp. 71-82). University of Westminster Press.

Kornfield, M. (2020). Health experts dispute conservatives' Claim that new study finds masks are ineffective. Washington Post. https://www.washingtonpost.com/health/2020/11/20/ mask-danish-study/.

Levitsky, S., \& Ziblatt, D. (2018). How democracies die. Viking Books.

Lind, M. (2016). Donald trump, the perfect populist. Politico Magazine. https://www.politico.com/ magazine/story/2016/03/donald-trump-the-perfect-populist-213697.

Linden, M. (2017). Trump's America and the rise of the authoritarian personality. The Conversation. $\quad$ https://theconversation.com/trumps-america-and-the-rise-of-the-authoritarian-perso nality-72770.

Long, H., and Clement, S. (2018). Trump voters hit hard by tariffs are standing by him-for now. The Washington Post. https://www.washingtonpost.com/business/2018/07/12/trump-voters-hit-hardby-tariffs-are-standing-by-him-now/.

Ludeke, S. G., Klitgaard, C. N., \& Vitriol, J. (2018). Comprehensively-measured authoritarianism does predict vote choice: The importance of authoritarianisms facets, ideological sorting, and the particular candidate. Personality and Individual Differences, 123, 209-216. https://doi.org/10. 1016/j.paid.2017.11.019

MacWilliams, M. C. (2016). The rise of trump: America's authoritarian spring. The Amherst College Press.

MacWilliams, M. C. (2020). On fascism. Griffin.

Malkin, M. (2019). Speech at the conservative political action conference. https://www.c-span.org/ video/?458347-42/cpac-michelle-malkin.

Moffitt, B. (2016). The global rise of populism. Stanford University Press.

Mudde, C. (2017). Populism: A very short introduction. Oxford University Press.

Muller, J.-W. (2021). Without trump, who is the future of trumpism. World Politics Review. https:// www.worldpoliticsreview.com/articles/29413/what-will-become-of-trump-s-populist-movement.

Muller, J.-W. (2016). What is populism? University of Pennsylvania Press. https://www.worldpolit icsreview.com/articles/29413/what-will-become-of-trump-s-populist-movement.

Norris, P., \& Inglehart, R. F. (2019). Cultural backlash: Trump, brexit, and authoritarian populism. Cambridge University Press.

Ross, A. (2016). The frankfurt school knew trump was coming. The New Yorker. https://www.newyo rker.com/culture/cultural-comment/the-frankfurt-school-knew-trump-was-coming.

Rowland, R. C. (2019). The populist and nationalist roots of trump's rhetoric. Rhetoric and Public Affairs, 22, 343-388. https://doi.org/10.14321/rhetpublaffa.22.3.0343

Sami, S. (2020). Trump supporters are the majority of those continuing to defy wearing masks. The Science Survey. https://thesciencesurvey.com/editorial/2020/11/12/trump-supporters-are-themajority-of-those-continuing-to-defy-wearing-masks/.

Sibley, C. G., \& Duckitt, J. (2013). The dual process model of ideology and prejudice: A longitudinal test during a global recession. The Journal of Social Psychology, 153(4), 448-466. https://doi. org/10.1080/00224545.2012.757544

Sidanius, J., \& Pratto, F. (1999). Social dominance: An intergroup theory of social hierarchy and oppression. Cambridge University Press.

Sides, J., Tesler, M., \& Vavreck, L. (2018). Identity crisis: The 2016 presidential campaign and the battle for the meaning of America. Princeton University Press.

Somit, A., \& Peterson, S. A. (1997). Darwinism, dominance, and democracy. Praeger.

Stenner, K. (2005). The authoritarian dynamic. Cambridge University Press.

Taub, A. (2016). The rise of American authoritarianism. Vox. https://www.vox.com/2016/3/1/11127 424/trump-authoritarianism.

Taylor, S., \& Asmundson, G. J. G. (2021). Negative attitudes about facemasks during the COVID-19 pandemic. PLoS ONE, 16(2), e0246317. https://doi.org/10.1371/journal.pone.0246317 
Viola-Gaudefroy, J. (2021). How Donald trump's populist narrative led directly to the assault on the U.S. Capitol. The Conversation. https://theconversation.com/how-donald-trumps-populist-narra tive-led-directly-to-the-assault-on-the-us-capitol-153277.

Walsh, J. (2019). Twitter post. https://twitter.com/WalshFreedom/status/1082655898387001344?s= 20.

Womick, J., Rothmund, T., Azevedo, F., King, L. A., \& Jost, J. T. (2018). Group-based dominance and authoritarian aggression predict support for Donald trump in the 2016 U.S. presidential election. Social Psychological and Personality Science, 10(5), 643-652. https://doi.org/10.1177/19485 50618778290

Publisher's Note Springer Nature remains neutral with regard to jurisdictional claims in published maps and institutional affiliations.

Springer Nature or its licensor (e.g. a society or other partner) holds exclusive rights to this article under a publishing agreement with the author(s) or other rightsholder(s); author self-archiving of the accepted manuscript version of this article is solely governed by the terms of such publishing agreement and applicable law. 